\title{
Analysis of the gastroprotective potential of the essential oil of Lippia gracilis Schauer (Verbenaceae) in experimental models of gastric ulcer: a brief review
}

Análise do potencial gastroprotetor do óleo essencial de Lippia gracilis Schauer (Verbenaceae) em modelos experimentais de úlcera gástrica: uma breve revisão

Análisis del potencial gastroprotector del aceite esencial de Lippia gracilis Schauer (Verbenaceae) en modelos experimentales de úlcera gástrica: una breve revisión

Layanne Cavalcante de Moura ORCID: https://orcid.org/0000-0003-2781-1076 Centro Universitário UNIFACID, Brasil

E-mail: layannecavalcante @ hotmail.com

Ana Graziela Soares Rêgo Lobão

ORCID: https://orcid.org/0000-0003-3003-954X

Centro Universitário Uninovafapi, Brasil

E-mail: grazielarego@hotmail.com

Samuel Lopes dos Santos

ORCID: https://orcid.org/0000-0003-3375-9171 Universidade Federal do Piauí, Brasil

E-mail: samuellopes121314@gmail.com

Joelma Maria dos Santos da Silva Apolinário

ORCID: https://orcid.org/0000-0001-9521-9432 Faculdade Maurício de Nassau, Brasil E-mail: jo.silva00@ hotmail.com

Samilly Lorâna Farias de Sousa ORCID: https://orcid.org/0000-0003-2647-9382 Universidade Potiguar, Brasil

E-mail: samilly.lorrana@yahoo.com.br

Weberton Dorásio Sobrinho

ORCID: https://orcid.org/0000-0003-0619-7214

Universidade de Rio Verde, Brasil

E-mail: dorasioweberton@gmail.com

Matheus da Silva Paulo

ORCID: https://orcid.org/0000-0002-0021-8240

Universidade Potiguar, Brasil

E-mail: matheus.paulo999@gmail.com

Jhônata Santos Brito

ORCID: https://orcid.org/0000-0002-8161-5677 
Viviane dos Santos Melo

ORCID: https://orcid.org/0000-0002-8659-828X Universidade Federal de Alagoas, Brasil E-mail: contatovivianemelo@gmail.com

Amanda Viana Santos

ORCID: https://orcid.org/0000-0002-4520-0634 Centro Universitário Tiradentes, Brasil E-mail: amandavianas@ hotmail.com Simone Barroso de Carvalho

ORCID: https://orcid.org/0000-0001-7428-8420 Universidade Federal do Piauí, Brasil

E-mail: simonebcarvalho2009@hotmail.com

Guilia Rivele Souza Fagundes

ORCID: https://orcid.org/0000-0003-1834-8278 Universidade do Estado da Bahia, Brasil E-mail: guilia_matina@hotmail.com

Moacir Andrade Ribeiro Filho

ORCID: https://orcid.org/0000-0003-1991-469X Universidade Regional do Cariri, Brasil E-mail: moacirarf@outlook.com

Mariana Pereira Barbosa Silva

ORCID: https://orcid.org/0000-0003-0852-8099 Universidade Estadual do Piauí, Brasil E-mail: marianapbsilvaa@gmail.com

Marianna Leite Barroso

ORCID: https://orcid.org/0000-0002-2147-7014

Faculdade São Francisco, Brasil

E-mail: mariannaleite_@hotmail.com

\begin{abstract}
Gastric ulcer is a disease that affects a large portion of the world population, with a prevalence of $2.4 \%$ in the Western population and annual incidence rates of $0.10 \%$ to $0.19 \%$, with a high cure rate, but with a high recurrence rate. The aim of this research is to perform a literature review on the gastroprotective potential of the essential oil of Lippia gracilis Schauer. To this end, an integrative review study was carried out, which selected 26 scientific articles found in virtual platforms that approached the proposed theme. Based on the established criteria, the literature suggests that the essential oil of Lippia gracilis Schauer is a compound with several biological activities, including some already described in the literature, however, its gastroprotective potential is still lacking many evidences in the literature. The findings show that the EO of $L$. gracilis can delay and bring an improvement in the degree of involvement by the ulcerative disorder. However, new scientific approaches are necessary to better elucidate the effect of this oil, which can then become an additional therapeutic method for cases of gastric lesions.
\end{abstract}

Keywords: Gastroprotective effect; Lippia gracilis Schauer; Gastric ulcer.

\title{
Resumo
}

A úlcera gástrica é uma doença que acomete grande parcela da população mundial, com prevalência de $2,4 \%$ na população ocidental e com taxas de incidência anuais de $0,10 \%$ a $0,19 \%$, com alta taxa de cura, porém com elevado índice de recorrência. O objetivo desta pesquisa é de fazer uma revisão de literatura sobre o potencial gastroprotetor do óleo essencial de Lippia gracilis Schauer. Para tanto foi realizado um estudo de revisão do tipo integrativa, que selecionou 26 artigos científicos encontrados em plataformas virtuais que abordam o tema proposto. Diante dos critérios estabelecidos, a literatura sugere que o óleo essencial de Lippia gracilis Schauer é um composto de várias atividades biológicas, inclusive com algumas já descritas na literatura, entretanto, tendo seu potencial gastroprotetor ainda sem muitas evidências na literatura. Os achados evidenciam que o $\mathrm{OE}$ de L. gracilis consegue retardar e trazer uma melhora no grau de acometimento pelo distúrbio ulcerativo. Contudo, novas abordagens científicas são necessárias, para que consiga-se elucidar melhor o efeito desse óleo, podendo então se tornar um método terapêutico adicional para casos de lesões gástricas.

Palavras-chave: Efeito gastroprotetor; Lippia gracilis Schauer; Úlcera gástrica.

\section{Resumen}

La úlcera gástrica es una enfermedad que afecta a una gran parte de la población mundial, con una prevalencia del $2,4 \%$ en la población occidental y unas tasas de incidencia anual del $0,10 \%$ al $0,19 \%$, con una alta tasa de curación, pero con una elevada tasa de recidiva. El objetivo de esta investigación es realizar una revisión bibliográfica sobre el potencial gastroprotector del aceite esencial de Lippia gracilis Schauer. Para ello, se realizó un estudio de revisión integrador, en el que se seleccionaron 26 artículos científicos encontrados en plataformas virtuales que abordan el tema propuesto. Teniendo en cuenta los criterios establecidos, la literatura sugiere que el aceite esencial de Lippia gracilis Schauer es un compuesto de diversas actividades biológicas, incluyendo algunas ya descritas en la literatura, sin embargo, teniendo su potencial gastroprotector sin mucha evidencia en la literatura. Los resultados muestran que 
el AE de L. gracilis puede retrasar y aportar una mejora en el grado de afectación del trastorno ulceroso. Sin embargo, se necesitan nuevos enfoques científicos para dilucidar mejor el efecto de este aceite, que puede convertirse en un método terapéutico adicional para los casos de lesiones gástricas.

Palabras clave: Efecto gastroprotector; Lippia gracilis Schauer; Úlcera gástrica.

\section{Introduction}

Gastric ulcer is characterized as a chronic disease and brings problems such as deep lesions in the gastric wall region, which invade and occupy the entire space of the mucosa. It is a disease that affects a large part of the population in the world, with an incidence of $2.4 \%$ in the Western population and annual rates of $0.10 \%$ to $0.19 \%$ and high cure rate; however, with a high recurrence picture (Kangwan et al., 2014).

This ulcerative disease occurs when a significant imbalance is observed between the aggressor factors, endogenous or exogenous (excessive alcohol consumption, smoking, stress, diet, use of nonsteroidal anti-inflammatory drugs (NSAIDs) infection by Helicobacter pylori bacteria, dysregulation in the secretion of pepsin and gastric acid), and mucosal protectors (mucus, bicarbonate, prostaglandins, sulfhydryl compounds, adequate blood flow, antioxidant system, and nitric oxide) (Rozza, 2013).

Currently, several classes of drugs and pharmaceuticals are used in the treatment and prophylaxis of gastric ulcer. Therapeutic methods consist of the use of proton pump inhibitors (e.g. omeprazole, pantoprazole, lansoprazole), histamine $\mathrm{H} 2$ receptor inhibitors (e.g. cimetidine, famotidine, nizatidine), antacids (e.g.: aluminum or magnesium hydroxide), antibiotics for H. pylori eradication (e.g. clarithromycin, amoxicillin), and gastric mucosal cytoprotective drugs such as prostaglandin analogues (e.g. misoprostol), carbenoxolone, and sucralfate (Fox; Muniraj, 2016).

Even though these drugs improve or cure gastric ulcers, they can have certain types of adverse effects, such as diarrhea, abdominal pain, arrhythmias, and intolerance in the gastrointestinal tract, among others. These substances act by stimulating the protective factors or by damaging the aggressors, and there are no ways that effectively address all the components involved (Abraham, 2012).

Thus, this scenario has triggered studies in search of new gastroprotective drugs, especially those obtained from natural products and their compounds, which can be highly effective in ulcer treatment, reduce the recurrence of lesions, have fewer side effects and be low cost (Kangwan et al., 2014).

In recent decades, the focus on the study of medicinal plants and their therapeutic principles has become evident, taking into account the large number of studies published on the subject in recent years. However, it is worth noting that the number of drugs from these plants is still negligible, with few getting approval from the Brazilian regulatory agency ANVISA, requiring new experimental studies in order to better elucidate the effects of these compounds against various metabolic problems (Dutra et al., 2016).

Natural products are a rich alternative in bioactive compounds and synthetics with effective pharmacological activities, and have been the sources of many substances with biological properties, for example, antioxidant and antiinflammatory activities, as well as bactericides, fungicides, useful in medicine for the treatment of various human disorders. A large portion of the population around the world still believes much in products based on medicinal plants (phytotherapy) to treat their diseases, which arouses the interest of several researchers in the area, in the study of the effects of these substances in several countries around the world (Silveira, 2008).

Among the natural products already described are essential oils, which are secondary metabolites synthesized in all parts of aromatic plants. These essential oils are in the form of compound volatile liquids, soluble in lipids, with a strong odor (Rozza, 2012).

Lippia gracilis Schauer (Verbenaceae), which is popularly known as "alecrimda-chapada" or "alecrim-da-serra", is an 
herb commonly found in the vegetation of northeastern Brazil. The essential oil of this species has high concentrations of monoterpenes, with thymol, carvacrol, o-cymene, $\gamma$-terpinene, and $\beta$-caryophyllene as its main components. Regarding this essential oil, several types of biological activities are evidenced in the literature, such as antinociceptive, anti-inflammatory, antioxidant and antimicrobial activities, the latter against Aedes aegypti larvae (Mendes et al., 2010; Riella et al., 2012).

Thus, knowing that there is a great economic and scientific interest in the discovery of new substances or alternative therapies based on natural products such as essential oils, and with a greater and specific interest in the essential oil of Lippia gracilis, the aim of this research is to make a literature review on the gastroprotective potential of this compound.

\section{Methodology}

To achieve the proposed objective, an integrative literature review was used. The integrative review is the analysis of relevant research that provides support for decision making and improvement of clinical practice. To operationalize the development of this review, six steps were followed: development of the research question, sampling or literature search of primary studies, data extraction, evaluation of the primary studies included, analysis and synthesis of results, and presentation of the review (Galvão, 2010).

To guide the integrative review, the following question was formulated: "What is the scientific evidence in the literature about the gastroprotective effect of Lippia gracilis Schauer essential oil?" The search for primary studies was performed according to the criteria and manuals of each database. Controlled descriptors were used (Health Science Descriptors) - Gastroprotective effect, Lippia gracilis Schauer, gastric ulcer (together and separately), combined with Boolean operators (AND and OR). The descriptors were searched between January and February 2021, in the databases: Scientific Electronic Library Online (SciELO), Latin American and Caribbean Literature on Health Sciences (LILACS) and Google Scholar.

The inclusion criteria for the delimited studies were articles that portrayed the essential oil of Lippia gracilis Schauer, published from January 2008 to February 2021, and with the following classifications: studies with experimental design, studies with non-experimental design, such as descriptive correlational and qualitative research or case studies, case reports or data obtained systematically, and literature reviews, published in Portuguese and English. The exclusion criteria established were: articles that did not address the topic in question, were written in languages other than those chosen for inclusion, studies published before 2010, and duplicates in divergent databases.

\section{Results and Discussion}

\subsection{Lippia gracilis Schauer (Verbenaceae) essential oil}

The research and use of medicinal plants and herbal medicines for the treatment of various diseases are currently being stimulated by the government. Since 2007, the SUS has made available to patients, through the state and municipal health departments, herbal medicines for the treatment of various diseases, such as Maytenus ilicifolia (Espinheira-santa), used in the treatment of ulcers and gastritis, and Mikania glomerata (Guaco), to treat flu symptoms (Brazil, 2012). From 2008 the National Program of Medicinal Plants and Herbal Medicines was put into effect, with approval of the Federal Government, which aims to ensure that the population has access to and safely enjoy the benefits of medicinal plants and herbal medicines, with investment in obtaining machinery and accessories, admission of trained technicians providing an association between all the pillars involved in the process of production and distribution of these medicines (Gomes, 2011).

The genus Lippia (Verbenaceae) is composed of about 200 species distributed throughout the countries of South and Central America and tropical Africa. A large part of part of this genus is popularly used to treat gastrointestinal and respiratory and respiratory disorders. Some species of Lippia already have proven antimalarial antiviral and cytostatic activities, among 
others. The literature reports that Lippia sidoides Cham has antimicrobial activity (Veras et al., 2014) and the Lippia citriodora has anticonvulsant activity (Rashidian et al., 2016).

Lippia gracilis Schauer (figure 1), or also known as "alecrim-dachapada" or "alecrim-da-serra" is an herb commonly found in the vegetation of northeastern Brazil, popularly used to treat diseases such as sinusitis, bronchitis, nasal congestion and pain. This species produces an essential oil (EO) containing as major components thymol, carvacrol, o-cymene, $\gamma$ terpinene-caryophyllene, used externally by the population to treat abdominal pain, skin diseases, burns, wounds and ulcers, as reviewed by Ferraz et al., (2013).

Figure 1. Lippia gracilis Schauer (Verbenaceae).

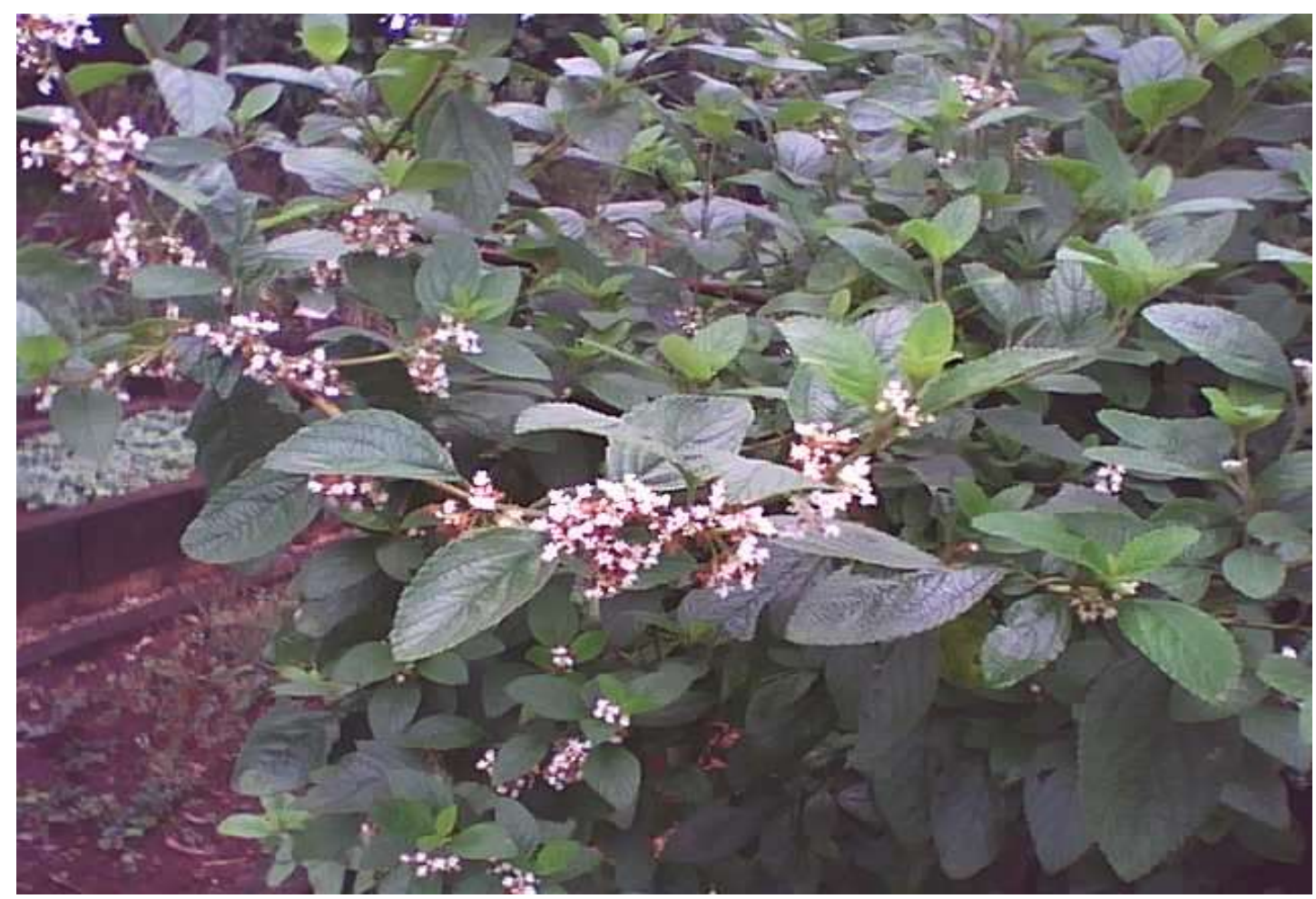

Source: Medicinal Plants (2021).

Studies suggest that the EO of Lippia gracilis Schauer already have several biological activities described in the literature (table 1), with its compounds being used for antimicrobial action (Silva et al., 2008), anti-inflammatory (Mendes et al., 2010) and now more recently, its gastroprotective activity (Martins, 2017). 
Table 1. Main biological activities of Lippia gracilis Schauer essential oil described in the literature.

\begin{tabular}{|c|c|c|}
\hline Article Title & Objective & Main results \\
\hline $\begin{array}{lcr}\text { Effects of } & \text { essential oils on Aedes } \\
\text { aegypti larvae: } & \text { Alternatives } & \text { to } \\
\text { environmentally } & \text { safe insecticides } & \end{array}$ & $\begin{array}{l}\text { Using essential oil from Lippia } \\
\text { gracilis Schauer and investigating } \\
\text { its larvicidal activity against } \\
\text { Aedes aegypti. }\end{array}$ & $\begin{array}{l}\text { Twenty larvae between the third and } \\
\text { fourth stages were added to the } \\
\text { essential oil solution. A mortality count } \\
\text { was performed } 24 \mathrm{~h} \text { after treatment. }\end{array}$ \\
\hline $\begin{array}{l}\text { Evaluation of the analgesic and anti- } \\
\text { inflammatory effects of the essential oil of } \\
\text { Lippia gracilis leaves }\end{array}$ & $\begin{array}{l}\text { The aim of the study is to } \\
\text { investigate the antinociceptive, } \\
\text { anti-inflammatory and antioxidant } \\
\text { activities of the essential oil (EO) } \\
\text { from leaves of Lippia gracilis } \\
\text { Schauer (Verbenaceae). }\end{array}$ & $\begin{array}{l}\text { Oral treatment with the EO of Lippia } \\
\text { gracilis leaves triggered inhibitory } \\
\text { activity on acetic acid effect at } 50,100 \text {, } \\
\text { and } 200 \mathrm{mg} / \mathrm{kg}(30.33 \pm 2.36,25.20 \pm \\
1.48 \text {, and } 21.00 \pm 1.54 \text { abdominal } \\
\text { bruising, respectively, } \mathrm{P}<0.05) \text {. }\end{array}$ \\
\hline $\begin{array}{l}\text { Gastroprotective effect of the essential oil } \\
\text { from Lippia gracilis Schauer (Verbenaceae) }\end{array}$ & $\begin{array}{l}\text { To evaluate the gastroprotective } \\
\text { effect of the essential oil of } \\
\text { Lippia gracilis. }\end{array}$ & $\begin{array}{l}\text { He action of EO on } \mathrm{H}+, \mathrm{K}+-\mathrm{ATPase} \\
\text { activity evaluated by in vitro assay. We } \\
\text { observed that OE dose-dependently } \\
\text { prevented ethanol/HCl-induced injury, } \\
\text { with decreased edema and epithelial } \\
\text { cell loss. }\end{array}$ \\
\hline
\end{tabular}

Source: Authors (2021).

\subsection{Pathological characterization of gastric ulcer}

Ulcer development is basically the result of an imbalance between mucosal protective mechanisms (mucus, bicarbonate, prostaglandins (PGs), nitric oxide (NO), non-protein sulfhydryl compounds (SH), antioxidant system, and mucosal blood flow) and harmful factors (increased secretion of gastric acid and pepsin, infection with the bacterial agent Helicobacter pylori, prolonged use of NSAIDs, improper diet, smoking, and excessive alcohol consumption) (Bi, 2014; Vieira, 2017).

Ulcer follows as one of the most prevalent diseases in the world, with over 300,000 cases diagnosed per year in the US, leading to costs in the billions of dollars. In South Korea in 2005, 20\% of adults who went to university hospital reported suffering from ulcers, and its incidence appears to be increasing in the elderly, making it a risk factor for mortality (Overmier; 2012; Leontiadis et al., 2013). It is estimated in Brazil an ulcer prevalence rate of $0.2 \%$ for men and $0.1 \%$ for women, with a mortality rate of 3.0/100,000 inhabitants (Oliveira et al., 2015).

\subsection{Gastroprotective effect of the essential oil from Lippia gracilis Schauer (Verbenaceae)}

In some studies that are considered experimental, the initial ulcer induction model is done in murine animals using substances such as ethanol/ $\mathrm{HCl}$, because it represents the effects of alcohol in humans. $\mathrm{HCl}$ causes severe damage to the gastric mucosa, while ethanol generates necrotic lesions by direct multifaceted action. These damages possibly stem from biological actions such as lipid peroxidation, free radical formation, and intracellular oxidative stress (Alrashdi et al., 2012). As shown, the EO of Lippia gracilis was able to prevent, in a dose-dependent manner, the gastric mucosal lesions induced by acidified ethanol; an event that was accompanied by a decrease in the inflammatory process (edema, cell loss) associated with gastric ulcer. In previous work conducted by our research group, it was demonstrated that the EO of L. gracillis presents antiinflammatory and antioxidant actions; therefore, its gastroprotective effect may be related, at least in part, to its antioxidant, in vitro and anti-inflammatory properties (Mendes et al., 2010).

In a study conducted by Martins (2017), the essential oil from Lippia gracilis leaves were obtained in 1.5\% yield. Twenty-one compounds were identified, representing $99.58 \%$ of the EO. The main compounds identified in the EO of Lippia gracilis, according to their retention indices were: carvacrol (34.72\%), thymol (16.08\%), pcimene (15.06\%), thymol methyl ether (7.18\%), (E)-caryophyllene (6.86\%) and $\gamma$-terpinene (5.07\%).

Further analyzed by Martins, the ethanol/HCl-induced gastric ulcer model, pretreatment with the EO of L. gracilis 
produced dose-dependent inhibition in total lesion areas $53.0 \%$ and $77.7 \%$ for $\mathrm{EO}$ at 60 and $180 \mathrm{mg} / \mathrm{kg}$, respectively. Administration of acidified ethanol was responsible for inducing consistent microscopic damage, which was characterized by rupture of the superficial region of the gastric gland with loss of epithelial cells, pronounced edema of the submucosa, and mucosal degradation, when compared to the naive (non-ulcerated) group. Animals treated with OE $(20,60 \mathrm{and} 180 \mathrm{mg} / \mathrm{kg}$ ) and omeprazole $(30 \mathrm{mg} / \mathrm{kg}$ ) showed less mucosal damage when compared to the vehicle group.

In 2011, Guilhon et al. sought to characterize the activities of EO and evaluate possible mechanisms involved. The results indicated that the EO of L. gracilis can inhibit inflammatory responses by blocking the NO pathway and can also attenuate hypernociception by blocking the opioid and cholinergic systems. Also in this study an acute toxicity evaluation was performed, where the animals were treated with the OE observed for analysis of behavioral parameters and later the stomachs collected for analysis of mucosal integrity, and the oral administration OE at $500 \mathrm{mg} / \mathrm{kg}$ dose did not induce any toxic effect, did not cause behavioral changes, injury or gastric bleeding.

It is believed that the gastroprotective effect of the EO of Lippia gracilis may result from a joint action of its constituents, since both the majority and minority constituents have gastroprotective activity described in the literature, with participation of different mechanisms in their respective effects.

Subsequently, Carli and co-workers (2015), exposed the role of 1,8-cineole as an ulcer healing agent, mentioning the possible mechanisms of action as: ability to increase gastric mucus; antioxidant action, preservation of sulfhydryl groups and attenuation of lipid peroxidation; and healing capacity.

Ribeiro et al. (2016) studied the monoterpene thymol, one of the majority constituents of the EO of L. gracilis, and found that it has gastroprotective actions in acute (ethanol and NSAIDs) and chronic (acetic acid) ulcers, an effect possibly mediated by prostaglandins and KATP channels, with an increase in the amount of mucus. The monoterpene carvacrol, another major constituent of L. gracilis EO, had its gastroprotective effect proven by Oliveira et al. (2012), in models of ulcers induced by ethanol, acidified ethanol, ibuprofen and ischemia/reperfusion.

These findings end up proving that natural products are important sources of substances for treatment of gastric ulcers, promoting its effect through various mechanisms, addressing protective and aggressive factors, which is not yet possible with the drugs currently used for the treatment of this disease.

\section{Conclusion}

The results obtained prove that the EO of Lippia gracilis has a treatment with the EO of Lippia gracilis increased mucus production and decreased gastric secretion.

Thus, these data trigger an important step for researchers in the area, with a view to creating a new therapeutic tool against gastric ulcer. It is hoped that, in light of these findings, new researchers will be able to carry out new research using this natural compound with other approaches in order to elucidate even more specifically histopathological, morphological, and immunohistochemical characterizations.

\section{References}

Abraham, N. S. (2012). Proton pump inhibitors: potential adverse effects. Current opinion in gastroenterology, 28(6), 615-620.

AlRashdi, A. S., Salama, S. M., Alkiyumi, S. S., Abdulla, M. A., Hadi, A. H. A., Abdelwahab, S. I., ... \& Asykin, N. (2012). Mechanisms of gastroprotective effects of ethanolic leaf extract of Jasminum sambac against $\mathrm{HCl}$ /ethanol-induced gastric mucosal injury in rats. Evidence-Based Complementary and Alternative Medicine, 2012.

Bi, W. P., Man, H. B., \& Man, M. Q. (2014). Efficacy and safety of herbal medicines in treating gastric ulcer: a review. World Journal of Gastroenterology: $W J G, 20(45), 17020$. 
Brasil. Ministério da Saúde. SUS tem fitoterápicos para doenças simples. Disponível em http://www.brasil.gov.br/saude/2012/11/sus-tem-fitoterapicosparadoencas-simples. Acesso em 09 de Agosto de 2016.

Carli, D. M. D., Pires, R. C., Rohde, S. L., Kavalco, C. M., \& Fagundes, R. B. (2015). Peptic ulcer frequency differences related to h. Pylori or aines. Arquivos de gastroenterologia, 52(1), 46-49.

Dutra, R. C., Campos, M. M., Santos, A. R., \& Calixto, J. B. (2016). Medicinal plants in Brazil: Pharmacological studies, drug discovery, challenges and perspectives. Pharmacological research, 112, 4-29.

Ferraz, R. P., Bomfim, D. S., Carvalho, N. C., Soares, M. B., da Silva, T. B., Machado, W. J., ... \& Bezerra, D. P. (2013). Cytotoxic effect of leaf essential oil of Lippia gracilis Schauer (Verbenaceae). Phytomedicine, 20(7), 615-621.

Fox, R. K., \& Muniraj, T. (2016). Pharmacologic therapies in gastrointestinal diseases. Medical Clinics, 100(4), 827-850.

Gomes, S. V. F., Nogueira, P. C. L., \& Moraes, V. R. S. (2011). Aspectos químicos e biológicos do gênero Lippia enfatizando Lippia gracilis Schauer. Eclética Química, 36(1), 64-77.

Guilhon, C. C., Raymundo, L. J., Alviano, D. S., Blank, A. F., Arrigoni-Blank, M. F., Matheus, M. E., ... \& Fernandes, P. D. (2011). Characterisation of the anti-inflammatory and antinociceptive activities and the mechanism of the action of Lippia gracilis essential oil. Journal of ethnopharmacology, 135(2), 406413.

Kangwan, N., Park, J. M., Kim, E. H., \& Hahm, K. B. (2014). Quality of healing of gastric ulcers: natural products beyond acid suppression. World journal of gastrointestinal pathophysiology, 5(1), 40 .

Leontiadis, G. I., Molloy-Bland, M., Moayyedi, P., \& Howden, C. W. (2013). Effect of comorbidity on mortality in patients with peptic ulcer bleeding: systematic review and meta-analysis. American Journal of Gastroenterology, 108(3), 331-345.

Martins, J. D. L., silva Ribeiro, A. R., da Silva, L. M., de Andrade, S. F., \& Thomazzi, S. M. (2018). EFEITO PROTETOR E ANTISECRETÓRIO DA Lippia gracilis SOBRE A MUCOSA ESTOMACAL DE ROEDORES. Semana de Pesquisa da Universidade Tiradentes-SEMPESq, (19).

Martins, J. D. L. (2017). Efeito gastroprotetor do óleo essencial da Lippia gracilis Schauer (verbenaceae).

Mendes, S. S., Bomfim, R. R., Jesus, H. C. R., Alves, P. B., Blank, A. F., Estevam, C. S., ... \& Thomazzi, S. M. (2010). Evaluation of the analgesic and antiinflammatory effects of the essential oil of Lippia gracilis leaves. Journal of Ethnopharmacology, 129(3), $391-397$.

Oliveira, A. F. D., Carvalho, J. R. D., Costa, M. D. F. D. S., Lobato, L. C. D. P., Silva, R. S. D., \& Schramm, J. M. D. A. (2015). Estimativa da prevalência e da mortalidade por complicações da úlcera péptica, Brasil, 2008: uma proposta metodológica. Epidemiologia e Serviços de Saúde, $24,145-154$.

Oliveira, I. S., da Silva, F. V., Viana, A. F. S., dos Santos, M. R., Quintans-Júnior, L. J., Maria do Carmo, C. M., ... \& de CM Oliveira, R. (2012). Gastroprotective activity of carvacrol on experimentally induced gastric lesions in rodents. Naunyn-Schmiedeberg's archives of pharmacology, 385(9), 899908.

Overmier, J. B., \& Murison, R. (2013). Restoring psychology's role in peptic ulcer. Applied Psychology: Health and Well-Being, 5(1), 5-27.

Rashidian, A., Farhang, F., Vahedi, H., Dehpour, A. R., Mehr, S. E., Mehrzadi, S., \& Rezayat, S. M. (2016). Anticonvulsant effects of Lippia citriodora (Verbenaceae) leaves ethanolic extract in mice: role of gabaergic system. International journal of preventive medicine, 7.

Ribeiro, A. R. S., Diniz, P. B., Pinheiro, M. S., Albuquerque-Júnior, R. L., \& Thomazzi, S. M. (2016). Gastroprotective effects of thymol on acute and chronic ulcers in rats: The role of prostaglandins, ATP-sensitive K+ channels, and gastric mucus secretion. Chemico-biological interactions, $244,121-128$.

Riella, K. R., Marinho, R. R., Santos, J. S., Pereira-Filho, R. N., Cardoso, J. C., Albuquerque-Junior, R. L. C., \& Thomazzi, S. M. (2012). Anti-inflammatory and cicatrizing activities of thymol, a monoterpene of the essential oil from Lippia gracilis, in rodents. Journal of Ethnopharmacology, $143(2)$, 656-663.

Rozza, A. L., \& Pellizzon, C. H. (2013). Essential oils from medicinal and aromatic plants: a review of the gastroprotective and ulcer-healing activities. Fundamental \& clinical pharmacology, 27(1), 51-63.

Silva, W. J., Dória, G. A. A., Maia, R. T., Nunes, R. S., Carvalho, G. A., Blank, A. F., ... \& Cavalcanti, S. C. H. (2008). Effects of essential oils on Aedes aegypti larvae: alternatives to environmentally safe insecticides. Bioresource technology, 99(8), 3251-3255.

Silveira, P. F. D., Bandeira, M. A. M., \& Arrais, P. S. D. (2008). Farmacovigilância e reações adversas às plantas medicinais e fitoterápicos: uma realidade. Revista Brasileira de Farmacognosia, 18(4), 618-626.

Veras, H. N. H., Rodrigues, F. F. G., Botelho, M. A., Menezes, I. R. A. D., Coutinho, H. D. M., \& Da Costa, J. G. M. (2014). Antimicrobial effect of Lippia sidoides and thymol on Enterococcus faecalis biofilm of the bacterium isolated from root canals. The Scientific World Journal, 2014.

Vieira, B. M., \& Nunes, C. P. (2017). H. Pylori versus úlcera gástrica nas eda do hctco. Revista da Faculdade de Medicina de Teresópolis, 1(01). 